JCCA Volume 7, Issue 2 \& 3, Autumn 2020

\title{
Urban Transformations and Contemporary Art in China
}

\author{
Editorial
}

Jiang Jiehong

In the recent decades, China has experienced an 'urban revolution' (e.g. Wu 2007;

Campanella 2008), whose scale and speed are unprecedented in human history for both the increase of construction projects and urban population. Existing scholarship on the topic explores the tangible and quantifiable aspects of the urban transformation, such as policy changes, physical development and expansion of cities including the construction boom, rural-urban migration, and inevitably, widening social inequality (e.g., Friedmann 2005; Hsing 2010; Zhang 2011). At the same time, more attention should be given to the intangible processes of transformation, such as how individual urban residents experience and perceive their changing cities through cultural means for a more holistic and multifaceted understanding of urban aspiration and its consequences in China.

'No construction without destruction' (bupo buli) - Chairman Mao's conclusive teaching was extended as an axiom for his Cultural Revolution, but also a prophecy for the dramatic urban developments of today. Construction in China does not merely constitute an effort towards improvement; it is a revolutionary action fundamentally to replace the old with an entirely new visual experience. The spirit behind the urban de/construction in contemporary China can be traced back to the early years of the People's Republic, when urban spaces, residential areas and everyday experiences were rearranged for both practical and ideological reasons (e.g. Meyer 2008; Gu et al. 2015). The changes continue all the way through the 'revolutions' in the last century, and are evident in the acceleration of economic and urban development since the Open-Door policy. Buildings, architectural complex, streets and even a whole city can be transitory from one to another that offers little trace of what has gone before. These incessant changes have shaped a moving reality, almost illusive, beyond the normal, tangible environment of daily life.

The rapidity of today's urbanisation is a global issue, and yet the example of contemporary urbanised China is unique, filled with excitement and anxiety. How do we re-examine the 
triumph of economic achievement and urban development, or the loss, through sociological, anthropological, cultural and artistic perspectives? For those insiders, in particular, artists who are living through accelerated development and its disturbance, how to capture and interpret the transient, to respond critically to such an urban existence, and to visualise the instability of everyday life, an extraordinary or almost surreal experience in China? This special issue has included discussions from a variety of subject areas through interdisciplinary perspectives and revealed new understandings on the development of artistic responses in the context of urban transformations.

In the last twenty years, I have been traveling to China regularly in recent years, for research and teaching. These trips are usually packed with lectures, meetings and visits, from one city to another, and neatly connected between airports, hotels, institutions and artist studios. I see China often, but only briefly at a time - from my hotel lounge, through taxi windows, over the tea set and dinner table with artists, colleagues and friends, and of course, at anytime and anywhere, on WeChat moments. In this Editorial, I would like to note a singular personal experience, provided as a background in response to the topic of this volume.

During one of those university trips, in October 2019, I jumped on a high-speed train in the morning traveling from Guangzhou to Changsha just for one day. Before the lecture that I was going to deliver at the College of Fine Arts, Hunan Normal University, Su Feng and her husband took me to lunch, with my suitcase. In the rain, I was a little tired but would never miss the opportunity of talking to the couple, or enjoying Hunan cuisine. 'It is an illusory place to dine ... one of the so-called wanghong (Internet famous) restaurants', Su Feng introduced on our way there. I was looking forward to it, but in the meantime, with my lecture in mind, I hoped that the lunch wouldn't be too overwhelming.

My first time to Changsha was in 2004, when I met Su Feng, who then was a young lady graduating from her postgraduate course in art. She later studied her PhD with us in Birmingham and has now become one of the senior staff members at the College and a mother of a child. In comparison with 2004, 15 years later, the city of Changsha is completely unrecognisable, the streets, the buildings and the traffic. Only Su Feng looks the same. 
We arrived at the entrance of a four or five-storey construction, like a large market or a multilayered town of the 1970 s and 8os - a banner reads 'Wenheyou Unlimited Company', leading to a seemingly endless world of small alleys, homes, retail stores, takeaways, barbershops, game rooms, cinemas, massage bars and public bathrooms [Figure 1]. They are all named after the original shops of the past, for example, the hundred-year-old Sanji Zhai for traditional bakery and Dongting Chun for tea. But the whole complex primarily is one entity, called the Wenheyou Old Changsha Restaurant, developed as part of a mega shopping mall right at the heart of the city centre [Figure 2]. Various dining units have been discreetly designed between residential places and shops, between private and public - some are open areas to accommodate multiple tables and benches and some can be found more exclusively at those reinvented home of, for instance, 'Aunty Peng' or 'Uncle Xu', as labelled on their door frames. We were led to the room of 'Teacher Zhou' located on the third floor. It was nothing like a commercial restaurant, but an invited visit to a home dining experience following a long journey through the lively environment of the old town. Although the 'host' was absent, the spice of the food was authentic.

This project was set up by a group of young men, led by the two founders Wen Bin and Weng Donghua. Over the years in the process of urban development, where numerous building deconstructions and home relocation were taking place, they have been collecting hundreds of thousands of discarded architectural components, furniture and daily objects which are then being used to restore a complete hometown of many inhabitants [Figure 3]. Every single detail, including doors and windows, the particular green colour of the walls, chairs, cabinets, TV, even broken cables, have been either commissioned or faithfully reproduced according to what had disappeared. Slogans on the streets, posters of movie stars in the living room and the popular songs of the time hovering above the visitors reinforce the immersive experience, while craftsmen of the community shout to offer local street food and souvenirs.

Both born in the late 1980 s and having grown up in Changsha, and more precisely, in the area when the current shopping mall is, the founders Wen and Weng (2019) state:

Although housing conditions were poor, the streets were muddy, it was our home, where happiness began... This work completely restores everything back to when we were children - homes, shops and the community; it invites disappearing craftsmen of the community to produce traditional things and local food, and to restart their business in order to live in an organic and sustainable way... During the last thirty years, China has undergone tremendous changes due to the explosive urban movement, resulting in same appearance of cities, same designs, and same rich people. To 
find our own way of survival and to return the origin of our happiness are the source of our inspiration.

In order to reject making another restaurant in familiar and identical shopping malls during globalised urban development today, the team has the strategy to achieve an alternative - not to build anything glossy and luxurious, modern glass curtain walls, fancy lighting or delicate tableware, but something that looks unpretentious and tarnished; not to pursue the new, but the old.

Today, memory as a subject becomes increasingly important within urban studies worldwide. For example, as Mark Crinson (2005: xi) discusses: 'the past is everywhere and it is nowhere. We seem at times overwhelmed by the oceanic feeling of a limitless archive, of which the city is the most physical example and the "memory" of our computers is the most ethereal yet the most trusted, and at others afflicted by a fear that the material traces of the past might be swept away, taking memory with them.' We are unsure if there is a place to store our memories in contemporary cities here, in which histories have been destroyed, and traditions and futures are being reinvented. A project like Wenheyou would only be successful in China, where the past can disappear so fast, within a few decades or even years, and when people who have experienced that past are all still alive. It revives a specific and an immediate past, rather than a past in distance, that of their ancestors and early generations. For example, a tourist village built in the Qing or Ming dynasty style and defined by a number of artificial arches, like Chinatown in the West, can only extend our curiosities of the unexperienced. Instead, this project was built for those who grew up locally, and they are paying a visit to that very past of their own, or in fact, returning home, like lost children. Strictly speaking, Wenheyou is not a past, but an interrupted story, as if a tape player was only paused and resumed again, for the song to continue. When everything else had carried on non-stop, there appears to be a lag, in which the lately arrived does not match with the current. And yet, it does not require any imagination but maintains an intrinsic power and capacity to re-accommodate the original community, its culture and social relations back in today's urban life. Every single detail - the visual, the sound and the smell, essentially, is not to recall any memory but to reiterate that this is a now. It is antimemory.

The lunch with colleagues was enjoyable, as always, and it felt especially long - as long as three decades. In spite of the fact that I was not from the region or familiar with the local 
dialect or culture there, the visual atmosphere, the language and typography of slogans, realistic gouache-painting posters and the soundscape of the music set in the background all brought me back to the 1980 s. On our way out, a fire exit door on a side of an alleyway was unintentionally left open, allowing us to peep into a whole new world of the next-door neighbour plaza - full of updated fashions and dazzling objects. While customers in the mall kept shopping for a tomorrow as usual, at the other side of a sheer partition wall, there were many of us, dinning, communicating and travelling in a yesterday of some thirty years ago, as usual. That fire exit door broke its promise to keep the past and the future separate. It must be kept closed at all time.

The greatest energy of art can only be obtained when it meets and engages with the reality of China's urban transformation and its states of immense change, and it is then released as a power in practice. There are many fire exit doors, located between memory and presentday, and between reality and imagination, whilst artists are the door keepers.

\section{References}

Campanella, Thomas J (2008), The Concrete Dragon: China's Urban Revolution and What It Means for the World. New York: Princeton Architectural Press.

Crinson, Mark (2005), 'Urban Memory: An Introduction', in Mark Crinson (ed.), Urban Memory: History and Amnesia in the Modern City. London: Routledge.

Friedmann, John (2005), China's Urban Transition. Minneapolis: University of Minnesota Press.

Gu, Chaolin, Wei, Yehua Dennis and Cook, Ian G (2015), 'Planning Beijing: socialist city, transitional city, and global city', in Urban Geography 36 (6), pp. 905-26.

Hsing, You-tien (2010), The Great Urban Transformation: Politics of Land and Property in China. London: Oxford University Press.

Meyer, Michael J (2008), The Last Days of Old Beijing: Life in the Vanishing Backstreets of a City Transformed. New York: Walker \& Co. 
Wen, Bin and Weng, Donghua (2019), unpublished statement.

Wu, Fulong (2007), 'Beyond Gradualism: China's urban revolution and emerging cities', in Fulong Wu (ed.), China's Emerging Cities: The Making of New Urbanism. New York: Routledge, pp. 3-25.

\section{Glossary}

bupo buli 不破不立

Dongting Chun 洞庭春

Sanji Zhai 三吉斋

wanghong 网红

Wenheyou 文和友 